\title{
Pemberian diet modifikasi komersial dan pengaruhnya terhadap asupan makanan dan status gizi pasien penyakit ginjal kronik prehemodialisis di RSUP DR. M. Djamil Padang
}

Pitri Balgis ${ }^{1}$, Probosuseno $^{2}$, Herni Astuti ${ }^{3}$

\begin{abstract}
Background: Chronic kidney disease causes progressive deterioration of kidney function and is commonly irreversible, leading to nausea and vomiting as a consequence of high ureum and creatinine in the blood. This condition results in declining appetite which greatly affects food intake and degrading nutritional status that causes high mortality among chronic kidney patients. Therefore efforts are made on how to increase intake of chronic kidney patients.

Objective: To identify the effect of nutrition therapy through commercial diet modification to nutrition intake and status of pre-hemodialysis chronic kidney patients at DR. M. Djamil Hospital, Padang.

Method: The study was a quasi experiment which used pre-test and post-test with control group design. Population of the study were all patients of pre-hemodialysis chronic kidney disease hospitalized at DR. M. Djamil Hospital of Padang. Samples were patients of pre-hemodialysis chronic kidney disease at internal medicine ward. The experiment group consisted of 11 patients who got modified diet within 6 days and control group consisted of 11 patients who got hospital standard diet with $\alpha=0.05$ and $\beta=10 \%$. The study were collected from January-March 2008. Data of intake were analyzed using Nutri Survey program. Statistical t-test and chi-square were used to identify the effect of commercial modified diet to food intake, nutritional status, and increase of ureum and creatinine. Absorption level was measured from the quantity of commercial nutrition used. Perception of the patients about commercial diet was obtained through questionnaires and analyzed to get the score.

Results: The group with modified diet had better energy and protein intake than the group with hospital standard diet ( $p$ $<0.05)$. However, there was no significant difference in nutritional status, ureum and creatinine changes between patients who got modified diet and those who got hospital standard diet $(p<0.05)$. The result of analysis on perception of patients about commercial diet showed that patients could accept commercial diet.

Conclusion: Commercial modified diet could increase intake of energy and protein of pre-hemodialysis chronic kidney patients.
\end{abstract}

KEY WORDS commercial modified diet, chronic kidney disease, pre-hemodialysis

\section{PENDAHULUAN}

Penyakit ginjal kronik merupakan kejadian penurunan fungsi ginjal yang menahun disebabkan oleh berbagai penyakit ginjal. Penyakit ini bersifat progresif dan umumnya tidak dapat pulih kembali (irreversible) (1). Pada keadaan ini, kemampuan ginjal untuk mengeluarkan hasil-hasil metabolisme tubuh telah terganggu, sehingga sisa-sisa metabolisme tersebut menumpuk dan menimbulkan gejala klinik dan laboratorium yang disebut sindrom uremik. Gejala-gejala sindrom uremik ini terutama disebabkan oleh penumpukan sisa-sisa katabolisme protein dan muncul sebagai gejala dari gangguan berbagai sistem dalam tubuh, sebagai contoh yang terlihat mencolok adalah gastrointestinal berupa rasa mual, muntah, dan kehilangan nafsu makan (anoreksia) (2).

Pasien dengan penyakit ginjal kronik memiliki manifestasi terjadinya malnutrisi. Penelitian Klahr (3) memperkirakan prevalensi malnutrisi pada pasien penyakit ginjal kronik sebesar 20-60\%, sedangkan menurut penelitian Krenitsky (4) diperkirakan sebanyak 40\%. Di Rumah Sakit Cipto Mangunkusumo (RSCM) juga dijumpai sebanyak $\pm 45 \%$ pasien penyakit ginjal kronik prehemodialisis yang mengalami status gizi kurang pada tahun 1991 dan 2002 (5). Hal ini berhubungan dengan peningkatan mortalitas pada pasien gagal ginjal.

Nafsu makan penderita penyakit ginjal kronik seringkali menurun akibat rasa mual yang hebat, sehingga makanan yang disajikan dari rumah sakit sering bersisa. Hal ini merupakan tantangan tersendiri bagi ahli gizi dalam menyusun diet dan menyediakan makanan yang seimbang bagi pasien penyakit ginjal kronik. Selain nafsu makan yang menurun, jenis-jenis bahan makanan yang mengandung kalori tinggi dan protein rendah, namun bernilai biologis tinggi sangat terbatas jumlahnya, terlebih lagi bila disertai dengan pembatasan kalium (6). Pada pasien penyakit ginjal kronik yang mengalami gangguan gizi, terjadinya anoreksia akan menghambat asupan energi yang tinggi. Untuk memenuhi kebutuhan energi tersebut, pasien dapat diberikan suplemen dari produk komersial yang merupakan sumber energi dengan kandungan protein yang rendah (7).

\footnotetext{
RSD Raden Mattaher Jambi, Jl. Letnan Jenderal Soeprapto No. 31 Telanaipura, Jambi

2 Bagian Penyakit Dalam RSUP Dr. Sardjito, Jl. Kesehatan, Yogyakarta 55281

3 Instalasi Gizi RSUP Dr. Sardjito, Jl. Kesehatan, Yogyakarta 55281
} 
Nutrisi enteral yang menggunakan oral nutrition suplement (ONS) dapat meningkatkan asupan zat gizi pasien yang memiliki asupan makan tidak adekuat. Pada pasien penyakit ginjal kronik, makanan mempunyai pengaruh yang kuat terhadap peningkatan asupan zat gizi. Oleh sebab itu, nutrisi enteral merupakan pilihan praktis dalam memenuhi kebutuhan pasien (8).

Makanan enteral dapat dikonsumsi sebagai makanan tambahan untuk memenuhi kebutuhan apabila pasien tidak dapat makan dalam jumlah cukup dengan bentuk makanan biasa (9). Salah satu upaya yang dapat dilakukan adalah melakukan modifikasi diet rendah protein dengan makanan khusus rendah protein yang bersifat komersial. Terdapat berbagai jenis makanan komersial yang merupakan sumber energi dengan kandungan protein yang rendah. Untuk menentukan produk komersial yang paling baik digunakan, sebaiknya memperhatikan beberapa hal seperti: fungsi saluran cerna pasien, kemampuan digestif dan absorbsi pasien, digestibilitas nutrient, komposisi nutrisi, kecukupan nutrisi, viskositas, osmolalitas, kemudahan penggunaan, dan biaya yang dibutuhkan. Toigo et al. (10) mengemukakan bahwa jika anoreksia terjadi pada pasien yang mengalami gangguan gizi akan menghambat asupan energi yang tinggi maka dapat diberikan suplemen yang merupakan sumber energi dengan kandungan rendah protein yang sudah tersedia dalam produk komersial dengan sumber protein berasal dari kasein dan perbandingan nitrogen dengan energi yang sudah dipertimbangkan.

Tujuan penelitian ini untuk mengetahui pengaruh pemberian terapi gizi melalui diet modifikasi komersial terhadap asupan makanan penderita penyakit ginjal kronik di RSUP DR. M. Djamil Padang.

\section{BAHAN DAN METODE}

Penelitian ini merupakan penelitian kuasi eksperimental yang dilakukan untuk menilai pengaruh pemberian diet modifikasi komersial terhadap asupan makanan dan status gizi pasien penyakitl ginjal kronik (11). Model rancangan penelitian ini adalah rancangan sebelum dan sesudah intervensi menggunakan kelompok pembanding eksternal (pre- and post-test with control group).

Penelitian dilakukan di RSUP DR. M. Djamil Padang mulai bulan Januari sampai dengan Maret 2008 dengan jumlah sampel yang dihitung menggunakan rumus pada tingkat kepercayaan $95 \%$ dan power test $90 \%$ (12). Pengambilan sampel dilakukan secara purposive sampling yaitu pasien yang ada di ruang rawat inap yang memenuhi kriteria inklusi dan eksklusi. Kriteria inklusi pada penelitian ini meliputi: pasien yang menderita penyakit ginjal kronik pada derajat 3 dan 4 yang didiagnosis oleh dokter, belum pernah menjalani hemodialisis, didukung oleh hasil pemeriksaan laboratorium dan pemeriksaan fisik tanpa komplikasi kecuali komplikasi dengan hipertensi, tidak mengalami anuria, telah menjalani rawat inap minimal selama 7 hari, makan secara oral, dan bersedia dijadikan sampel penelitian. Kriteria eksklusi pada penelitian ini meliputi: penderita dengan komplikasi diabetes mellitus dan pasien yang mendapat diet cair.

Besar sampel yang diperoleh sebanyak 22 orang yang dihitung berdasarkan rumus pengujian hipotesis untuk dua rata-rata populasi (12). Di antara sampel tersebut, 11 orang mendapat perlakuan (kelompok perlakuan) dan 11 orang dijadikan kontrol (kelompok kontrol). Untuk menentukan kelompok yang mendapat diet modifikasi komersial (kelompok perlakuan) dan yang mendapat diet standar rumah sakit (kelompok kontrol), subjek dipilih dengan cara lotre.

Diet standar rumah sakit yang diberikan merupakan diet rendah protein yang mengandung energi sebesar $1.800 \mathrm{kkal}$ dan protein sebesar $40 \mathrm{~g}$, sedangkan diet modifikasi komersial merupakan diet rendah protein yang diberikan kepada pasien penyakit ginjal kronik prehemodialisis yang telah diubah bentuk dan waktu pemberiannya. Pada diet modifikasi komersial, dua pertiga dari kebutuhan energi dan protein pasien diberikan dari diet standar rumah sakit dan satu pertiga sisanya diberikan dalam bentuk diet komersial khusus rendah protein. Diet modifikasi komersial ini diberikan sebanyak 600 $\mathrm{mL}$ dengan kandungan total energi sebanyak $600 \mathrm{kkal}$ dan protein sebanyak $11,7 \mathrm{~g}$ dalam 3 kali pemberian. Pemberian dilakukan selama 6 hari dan diberikan mulai hari kedua pasien dirawat. Waktu pemberian makan pasien yang biasanya 5 kali diganti menjadi 6 kali tanpa mengubah kebutuhan pasien.

Data yang dikumpulkan meliputi: data berat badan, tinggi badan, asupan makanan, hasil laboratorium mengenai ureum dan kreatinin, status gizi diukur menggunakan subjective global assessment (SGA), serta daya terima pasien terhadap produk diet komersial. Data asupan makanan dianalisis dengan menggunakan Program Nutri Survey dan uji statistik dengan chi square test dan t-test.

\section{HASIL DAN BAHASAN}

\section{Karakteristik subjek penelitian}

Karakteristik subjek penelitian dapat dilihat pada Tabel 1. Jenis kelamin subjek laki-laki lebih banyak daripada perempuan, baik pada kelompok kontrol maupun kelompok perlakuan. Subjek yang berumur 40 tahun ke atas pada kelompok kontrol lebih sedikit dibanding pada kelompok perlakuan, masing-masing sejumlah $72,7 \%$ dan $90,9 \%$, namun subjek yang berumur di bawah 40 tahun pada kelompok kontrol lebih banyak dibanding pada kelompok perlakuan, masing-masing sebanyak $27,3 \%$ dan $9,1 \%$. Hasil uji statistik membuktikan bahwa tidak ada perbedaan bermakna pada umur dan jenis kelamin antara kelompok kontrol dan perlakuan $(p>0,05)$.

Jenis kelamin dan umur merupakan faktor-faktor yang berpengaruh terhadap kebutuhan metabolisme basal, sehingga antara laki-laki dan perempuan dengan umur, tinggi, 
TABEL 1. Karakteristik subjek penelitian

\begin{tabular}{|c|c|c|c|c|c|c|}
\hline \multirow[t]{2}{*}{ Karakteristik } & \multicolumn{2}{|c|}{ Perlakuan } & \multicolumn{2}{|c|}{ Kontrol } & \multirow{2}{*}{$\chi^{2}$} & \multirow{2}{*}{$\mathbf{p}$} \\
\hline & $\mathbf{n}$ & $\%$ & $\mathbf{n}$ & $\%$ & & \\
\hline \multicolumn{7}{|l|}{ Jenis kelamin } \\
\hline Laki-laki & 8 & 72,7 & 8 & 72,7 & 0,00 & 1,000 \\
\hline Perempuan & 3 & 27,3 & 3 & 27,3 & & \\
\hline \multicolumn{7}{|l|}{ Umur } \\
\hline$<40$ tahun & 1 & 9,1 & 3 & 27,3 & 1,222 & 0,568 \\
\hline$\geq 40$ tahun & 10 & 90,9 & 8 & 72,7 & & \\
\hline \multicolumn{7}{|l|}{ Asupan energi } \\
\hline Cukup & 6 & 54,5 & 1 & 9,1 & 5,238 & 0,063 \\
\hline Tidak cukup & 5 & 45,5 & 10 & 90,9 & & \\
\hline \multicolumn{7}{|l|}{ Asupan protein } \\
\hline Cukup & 8 & 72,7 & 3 & 27,3 & 4,54 & 0,086 \\
\hline Tidak cukup & 3 & 27,3 & 8 & 72,7 & & \\
\hline
\end{tabular}

dan berat badan berbeda mempunyai komposisi tubuh yang berbeda pula. Perempuan mempunyai jaringan lemak lebih banyak, sehingga memiliki otot yang lebih sedikit daripada laki-laki. Hal ini menyebabkan angka metabolisme basal menurun dan pada usia muda kebutuhan metabolisme basal lebih tinggi daripada usia tua (13). Menurut Mandayam dan Mitch (14), diperkirakan dua pertiga orang normal yang berumur di atas 40 tahun mengalami penurunan laju filtrasi glomerulus, tetapi tidak mengalami penyakit ginjal. Pada analisis univariat, subjek dengan jenis kelamin laki-laki mengalami penurunan laju filtrasi glomerulus lebih cepat, namun tidak selalu terjadi pada analisis multivariat (15).

Berdasarkan kecukupan energinya, jumlah subjek yang memiliki asupan energi cukup pada kelompok perlakuan sebelum intervensi lebih tinggi dibanding kelompok kontrol, masing-masing sebesar $54,5 \%$ dan $9,1 \%$. Hasil uji statistik chi square yang dilakukan terhadap asupan energi menurut kebutuhan menunjukkan tidak ada perbedaan yang bermakna antara kelompok perlakuan dengan kelompok kontrol $(p>0,05)$.

Demikian pula tingkat asupan protein pada kelompok perlakuan sebelum intervensi umumnya sudah cukup, sedangkan pada kelompok yang tidak mendapat perlakuan asupan protein pada umumnya memiliki tingkat asupan protein tidak cukup, dengan jumlah subjek masing-masing $72,7 \%$. Hasil uji statistik chi square yang dilakukan terhadap asupan protein menunjukkan tidak ada perbedaan yang bermakna antara kelompok perlakuan dengan kelompok kontrol $(p>0,05)$.

\section{Pengaruh diet modifikasi komersial terhadap asupan energi dan protein}

Pengaruh diet modifikasi komersial terhadap asupan energi Pada penelitian ini diperoleh rata-rata asupan energi yang berasal dari rumah sakit pada kelompok perlakuan lebih tinggi $(1.409,4 \mathrm{kkal})$ dibandingkan dengan kelompok yang tidak mendapat perlakuan ( $891,0 \mathrm{kkal})$. Secara keseluruhan, total asupan energi baik dari rumah sakit maupun dari luar rumah sakit pada kelompok perlakuan lebih tinggi (1.446,9 kkal) dibandingkan dengan kelompok kontrol $(958,1$ kkal). Hasil analisis menggunakan $t$ - test menunjukkan ada perbedaan bermakna asupan energi dari rumah sakit antara kelompok perlakuan dengan kelompok kontrol $(p<0,05)$, begitu juga dengan total asupan energi (Tabel 2).

Pada penelitian ini terdapat kenaikan asupan energi pada kelompok perlakuan yang mendapat diet modifikasi komersia sebesar 488,8 kkal. Kenaikan ini lebih tinggi jika dibandingkan dengan penelitian yang dilakukan oleh Sunaryo (16) yang membuktikan bahwa kenaikan asupan energi pada pasien

TABEL 2. Hasil analisis rata-rata asupan energi dan protein pada kelompok kontrol dan perlakuan

\begin{tabular}{ccccc}
\hline \multirow{2}{*}{ Variabel } & \multicolumn{2}{c}{ Mean \pm SD } & \multirow{2}{*}{ IK 95\% } & \multirow{2}{*}{ p } \\
\cline { 2 - 3 } & Perlakuan & Kontrol & & \\
\hline Asupan energi (kkal/hari) & $1409,4 \pm 347,9$ & $891,0 \pm 313,6$ & $-813,1--223,8$ & $0,02^{*}$ \\
Rumah sakit & $37,5 \pm 28,1$ & $75,2 \pm 55,2$ & $-1,25-76,6$ & 0,62 \\
Luar rumah sakit & $1446,9 \pm 354,8$ & $958,1 \pm 305,5$ & $-782,9--195,0$ & $0,03^{*}$ \\
Total & & & & \\
Asupan protein (g/hari) & $32,6 \pm 8,8$ & $19,4 \pm 7,5$ & $-20,5--6,0$ & $0,01^{*}$ \\
Rumah sakit & $0,7 \pm 0,8$ & $1,2 \pm 1,6$ & $-0,7-1,5$ & 0,44 \\
Luar rumah sakit & $33,4 \pm 9,1$ & $20,6 \pm 7,9$ & $-20,4--5,2$ & $0,00^{*}$ \\
Total & & & &
\end{tabular}

Keterangan:

*Signifikan $(p<0,05)$ 
penyakit ginjal kronik prehemodialisis yang mendapat diet modifikasi hanya $147 \mathrm{kkal}$ (modifikasi dilakukan terhadap menu pasien). Perbedaan ini disebabkan pada pasien penyakit ginjal kronik yang mengalami gangguan gizi, terjadinya anoreksia akan menghambat asupan energi yang tinggi. Untuk memenuhi kebutuhan energi tersebut, pasien dapat diberikan suplemen dari produk komersial yang merupakan sumber energi dengan kandungan protein yang rendah berasal dari kasein dan perbandingan nitrogen dengan energi yang sudah dipertimbangkan (7).

Secara keseluruhan, asupan energi pada kelompok kontrol dan kelompok perlakuan masih tergolong rendah, yaitu di bawah $90 \%$ jika dibanding kebutuhan energinya. Hal ini disebabkan pada penderita penyakit ginjal kronik sering mengalami mual, muntah, anoreksia, dan gangguan lainnya, sehingga asupan zat gizi tidak adekuat/tidak mencukupi (2).

Pengaruh diet modifikasi komersial terhadap asupan protein Rata-rata asupan protein rumah sakit pada kelompok perlakuan sebesar $32,6 \mathrm{~g}$, lebih tinggi dibandingkan dengan kelompok kontrol sebesar 19,4 g. Begitu pula dengan total asupan protein yang menunjukkan bahwa pada kelompok perlakuan asupan proteinnya lebih tinggi yaitu sebesar 33,4 $\mathrm{g}$ dibandingkan dengan kelompok kontrol sebesar 20,6 g. Setelah dilakukan $t$-test, diperoleh hasil ada perbedaan bermakna asupan protein antara kelompok perlakuan dengan kelompok kontrol, baik pada asupan protein yang berasal dari rumah sakit maupun total asupan protein $(p<0,05)$, sedangkan asupan protein yang berasal dari luar rumah sakit tidak menunjukkan perbedaan yang bermakna antara kelompok perlakuan dengan kelompok kontrol $(p>0,05)$. Perbedaan rata-rata asupan protein kelompok yang mendapat diet modifikasi komersial dibandingkan dengan yang mendapatkan diet standar rumah sakit sebesar $13,2 \mathrm{~g}$ (terjadi peningkatan asupan protein pada pasien yang mendapat diet modifikasi komersial) (Tabel 2).

Asupan protein pada pasien yang diberikan diet modifikasi komersial pada penelitian ini sudah mencukupi kebutuhan, namun pada penelitian Sunaryo (15) membuktikan bahwa asupan protein rata-rata pada pasien penyakit ginjal kronik yang mendapat diet standar rumah sakit lebih besar daripada penelitian ini yaitu sebesar $34,89 \mathrm{~g}$. Hal ini disebabkan adanya tambahan makanan yang merupakan sumber protein dari luar rumah sakit, sedangkan pada penelitian ini hanya sedikit makanan dari luar rumah sakit karena setiap pasien dianjurkan untuk mengutamakan mengkonsumsi makanan yang diberikan dari rumah sakit serta memberitahukan pantangan dan pilihan jenis makanan yang dianjurkan

\section{Pengaruh diet modifikasi komersial terhadap status gizi}

Saat awal penelitian, pasien pada kelompok perlakuan yang memiliki status gizi baik sebesar $36,4 \%$. Persentase tersebut lebih tinggi dibanding pasien pada kelompok kontrol yang sebesar $18,2 \%$, sedangkan pasien yang memiliki status gizi buruk pada kelompok kontrol sebesar 9,1\% dan lebih sedikit dibandingkan dengan pasien pada kelompok yang mendapat perlakuan yaitu sebesar $18,2 \%$. Pada akhir penelitian, ternyata terjadi kenaikan jumlah kelompok perlakuan yang memiliki status gizi baik menjadi sebesar $45,5 \%$, sedangkan pada kelompok kontrol terjadi kenaikan jumlah yang menderita gizi buruk menjadi sebesar $27,3 \%$. Dari hasil t-test diketahui pada awal penelitian tidak ada perbedaan yang bermakna antara kelompok yang mendapat perlakuan dengan kelompok kontrol $(p>0,05)$, begitu juga pada akhir penelitian (Tabel 3).

Penelitian yang dilakukan oleh Caravaca et al. (17) yang melakukan pengukuran status gizi terhadap pasien penyakit ginjal kronik predialisis dengan munggunakan SGA melaporkan bahwa pasien yang menderita gizi sedang dan buruk sebanyak $36 \%$ dan yang tidak mempunyai masalah gizi sebanyak $64 \%$. Menurut Krenitsky (4), malnutrisi terjadi sampai angka $40 \%$ pada pasien dengan gagal ginjal. Penyebab dari malnutrisi tersebut bersifat multifaktor, tetapi hasil survei membuktikan bahwa penyebab utamanya adalah asupan makanan yang tidak adekuat dan gangguan gastrointestinal.

Meskipun penelitian ini menunjukkan hasil yang tidak bermakna, namun ada perbaikan status gizi pada pasien yang mendapat diet modifikasi komersial dan hal ini berhubungan dengan adanya peningkatan asupan pada pasien tersebut.

\section{Pengaruh diet modifikasi komersial terhadap nilai ureum}

Hasil analisis menunjukkan bahwa rata-rata ureum awal pada kelompok kontrol lebih tinggi, yaitu sebesar $184,5 \mathrm{mg} /$ $\mathrm{dL}$ dibanding kelompok perlakuan yang hanya sebesar 157,7

TABEL 3. Perbedaan status gizi awal dan akhir pada kelompok perlakuan dan kontrol

\begin{tabular}{ccccccc}
\hline \multirow{2}{*}{ Variabel } & \multicolumn{2}{c}{ Perlakuan } & \multicolumn{2}{c}{ Kontrol } & \multirow{2}{*}{$\chi^{\mathbf{2}}$} & \multirow{2}{*}{$\mathbf{p}$} \\
\cline { 2 - 4 } & $\mathbf{n}$ & $\mathbf{\%}$ & $\mathbf{n}$ & $\mathbf{\%}$ & & \\
\hline Status gizi awal & & & & & & \\
Baik & 4 & 36,4 & 2 & 18,2 & 0,426 & 0,993 \\
Sedang & 5 & 45,5 & 8 & 72,7 & & \\
Kurang & 2 & 18,2 & 1 & 9,1 & & \\
Status gizi akhir & & & & & & \\
Baik & 5 & 45,5 & 1 & 9,1 & 0,853 & 0,461 \\
Sedang & 4 & 36,4 & 7 & 63,6 & & \\
Kurang & 2 & 18,2 & 3 & 27,3 & & \\
\hline
\end{tabular}


$\mathrm{mg} / \mathrm{dL}$. Hasil analisis statistik menunjukkan tidak ada perbedaan bermakna nilai rata-rata ureum awal pada kedua kelompok ( $p>0,05)$. Hasil analisis terhadap ureum akhir penelitian pada kelompok perlakuan juga lebih rendah yaitu sebesar $142,2 \mathrm{mg} / \mathrm{dL}$ dibanding kelompok kontrol yang sebesar 196,7 mg/dL, namun di antara kedua kelompok terdapat perbedaan yang bermakna $(p<0,05)$ (Tabel 4).

Berdasarkan hasil analisis rata-rata selisih ureum pada kelompok kontrol lebih tinggi (12,2 mg/dL) dibanding kelompok perlakuan $(4,6 \mathrm{mg} / \mathrm{dL})$. Setelah dilakukan $t$-test, hasilnya menunjukkan tidak ada perbedaan yang bermakna pada kedua kelompok ( $p>0,05)$ (Tabel 5).

Tingginya ureum darah pada penderita penyakit ginjal tersebut disebabkan kemampuan ginjal untuk mengeluarkan hasil-hasil metabolisme telah terganggu, sehingga sisa metabolisme menumpuk dan menimbulkan gejala klinik dan laboratorium yang disebut sindrom uremik (2).

Urea merupakan hasil akhir dari metabolisme nitrogen dan jumlahnya akan meningkat pada kondisi (glomerular filtration rate) menurun. Konsentrasi urea dalam darah juga bergantung pada besarnya asupan nitrogen dan keseimbangan antara sintesis protein dari dalam serta tingkat kerusakan ginjal (18). Menurut Djarwoto (19), kadar urea dalam darah juga dipengaruhi oleh asupan protein yang berlebihan, perdarahan gastrointestinal, hiperkatabolik, obat kortikosteroid-tetrasiklin, disfungsi hati, dan malnutrisi protein. Pasien yang mengalami uremia dan sisa metabolisme nitrogen lainnya serta toksik uremik dapat diminimalisasikan dengan pemberian diet rendah protein (7).

Pemberian 0,6 g protein $/ \mathrm{kg} /$ hari dapat mempertahankan kondisi yang netral atau protein positif dan keseimbangan nitrogen sepanjang asupan energi tidak berkurang (20). Ureum yang tinggi selain disebabkan asupan protein yang tinggi dapat pula disebabkan katabolisme protein tubuh (21).
Walaupun hasil penelitian tidak menunjukkan perbedaan yang bermakna, pada akhir penelitian tejadi penurunan nilai ureum pada kelompok yang mendapat perlakuan dan terjadi kenaikan nilai ureum pada kelompok kontrol.

\section{Pengaruh pemberian diet modifikasi komersial terhadap nilai kreatinin}

Nilai awal kreatinin pada pasien yang mendapatkan perlakuan sebesar $4,8 \mathrm{mg} / \mathrm{dL}$ dan lebih tinggi dibanding kontrol yang hanya sebesar $4,7 \mathrm{mg} / \mathrm{dL}$, namun pada akhir penelitian nilai kreatinin pasien yang mendapat perlakuan lebih rendah $(6,0 \mathrm{mg} / \mathrm{dL})$ dibanding kelompok kontrol $(6,6 \mathrm{mg} / \mathrm{dL})$. Hasil uji statistik menunjukkan hasil yang tidak bermakna antara kedua kelompok, baik pada awal penelitian maupun pada akhir penelitian ( $p>0,05)$ (Tabel 6).

Pada penelitian ini juga dilakukan analisis terhadap nilai selisih kreatinin yang hasilnya menunjukkan pada kelompok kontrol lebih tinggi $(1,9 \mathrm{mg} / \mathrm{dL})$ dibanding kelompok perlakuan $(1,2 \mathrm{mg} / \mathrm{dL})$ dan tidak berbeda secara bermakna $(p>0,05)$ (Tabel 5).

Menurut Sidabutar (22), ureum darah dan kretinin serum naik pada kondisi tertentu seperti hiperkatabolisme dan dapat menurun pada saat diet rendah protein. Pada kedua kelompok baik yang mendapat diet modifikasi komersial maupun yang tidak mendapat diet modifikasi komersial ternyata tetap terjadi kenaikan kreatinin. Kreatinin merupakan produk dari jaringan otot dan jumlah kreatinin dalam serum atau plasma menunjukkan kerusakan ginjal yang tetap tinggi. Hal ini disebabkan sisa metabolik yang seharusnya diekskresi melalui urin akan tetap menumpuk dalam tubuh karena laju filtrasi menurun dan juga merupakan gejala uremik (18). Peningkatan kreatinin dapat juga disebabkan oleh obat-obatan (19). Asupan protein hanya mempunyai sedikit efek terhadap ekskresi kreatinin urin, karena bahan utama dari kreatinin yaitu berasal dari arginin dan glisin (23).

TABEL 4. Hasil analisis rata-rata ureum pada kelompok perlakuan dan kontrol saat awal dan akhir penelitian

\begin{tabular}{|c|c|c|c|c|}
\hline \multirow[b]{2}{*}{ Variabel } & \multicolumn{2}{|c|}{ Mean \pm SD } & \multirow{2}{*}{ IK 95\% } & \multirow{2}{*}{$\mathbf{p}$} \\
\hline & $\begin{array}{c}\text { Perlakuan } \\
(\mathrm{n}=11)\end{array}$ & $\begin{array}{l}\text { Kontrol } \\
(n=11)\end{array}$ & & \\
\hline Ureum awal & $157,7 \pm 57,4$ & $184,5 \pm 72,9$ & $-31,6-85,1$ & 0,351 \\
\hline Ureum akhir & $142,2 \pm 48,2$ & $196,7 \pm 69,5$ & $1,3-107,6$ & $0,045^{*}$ \\
\hline
\end{tabular}

Keterangan:

*Signifikan $(p<0,05)$

TABEL 5. Hasil analisis selisih ureum dan kreatinin pada kelompok perlakuan dan kontrol

\begin{tabular}{|c|c|c|c|c|}
\hline \multirow[b]{2}{*}{ Variabel } & \multicolumn{2}{|c|}{ Mean \pm SD } & \multirow[b]{2}{*}{ IK 95\% } & \multirow[b]{2}{*}{$\mathbf{p}$} \\
\hline & $\begin{array}{l}\text { Perlakuan } \\
(n=11)\end{array}$ & $\begin{array}{l}\text { Kontrol } \\
(n=11)\end{array}$ & & \\
\hline Selisih ureum & $4,6 \pm 88,8$ & $12,2 \pm 64,0$ & $-61,2-78,4$ & 0,819 \\
\hline Selisih kreatinin & $1,2 \pm 3,0$ & $1,9 \pm 3,0$ & $-1,93-3,4$ & 0,578 \\
\hline
\end{tabular}




\section{Daya terima diet komersial}

Hasil penelitian menunjukkan bahwa dari $600 \mathrm{~mL}$ produk diet komersial yang diberikan kepada pasien setiap hari, dapat dihabiskan rata-rata sebesar $536 \mathrm{~mL}$ (89\%) yang mengandung $536 \mathrm{kkal}$ dan $12,5 \mathrm{~g}$ protein. Dari total asupan pada kelompok yang mendapat perlakuan, $37 \%$ merupakan sumbangan dari diet komersial.

Hasil penelitian persepsi pasien terhadap produk diet komersial menunjukkan bahwa dari 11 orang yang mendapat perlakuan, $82 \%$ di antaranya menyatakan suka dan $18 \%$ menyatakan tidak suka (Tabel 7).

\section{KESIMPULAN DAN SARAN}

Asupan energi dan protein pasien penyakit ginjal kronik yang mendapat diet modifikasi komersial lebih baik daripada yang mendapatkan diet standar rumah sakit, namun tidak ada perbedaan yang bermakna terhadap perubahan status gizi pasien yang mendapat diet modifikasi komersial dengan pasien yang mendapat diet standar rumah sakit. Selain itu, tidak ada perbedaan yang bermakna terhadap perubahan kadar ureum dan kreatinin pada pasien penyakit ginjal kronik setelah mendapat diet modifikasi komersial dengan diet standar rumah sakit. Hasil analisis daya terima terhadap salah satu produk diet komersial juga menunjukkan bahwa sebagian besar pasien penyakit ginjal kronik dapat menerima produk tersebut.

Rekomendasi untuk penelitian ini adalah perlu dilakukan modifikasi diet rendah protein yang sudah dijadikan standar rumah sakit dengan komersial dengan alasan dapat meningkatkan asupan pasien penyakit ginjal kronik dan memiliki nilai biologis tinggi dibanding diet standar rumah sakit.

\section{Ucapan terima kasih}

Penelitian ini terlaksana berkat dukungan RSUP DR M. Djamil Padang. Pada kesempatan ini kami ucapkan terima kasih kepada Direktur RSUP DR. M. Djamil Padang dan Direktur RSD Raden Mattaher Jambi, atas izin dan dukungan sehingga penelitian ini dapat terlaksana .

Ucapan terima kasih kami sampaikan juga kepada Kepala Instalasi Gizi, Kepala Ruangan Penyakit Dalam RSUP DR. M. Djamil Padang, dan responden yang terlibat dalam penelitian ini.

TABEL 6. Hasil analisis rata-rata kreatinin pada kelompok perlakuan dan kontrol saat awal dan akhir penelitian

\begin{tabular}{lcccc}
\hline & \multicolumn{2}{c}{ Mean \pm SD } & & IK 95\% \\
\cline { 2 - 3 } Variabel & $\begin{array}{c}\text { Perlakuan } \\
(\mathbf{n}=\mathbf{1 1})\end{array}$ & $\begin{array}{c}\text { Kontrol } \\
(\mathbf{n}=\mathbf{1 1 )}\end{array}$ & IK & \\
\hline Kreatinin awal & $4,8 \pm 3,0$ & $4,7 \pm 3,0$ & $-2,3-2,1$ & 0,912 \\
Kreatinin akhir & $6,0 \pm 5,2$ & $6,6 \pm 3,6$ & $-3,3-4,6$ & 0,754 \\
\hline
\end{tabular}

TABEL 7. Persepsi pasien terhadap diet komersial

\begin{tabular}{lcc}
\hline \multicolumn{1}{c}{ Daya terima } & $\mathbf{n}$ & $\mathbf{\%}$ \\
\hline Suka & 9 & 82 \\
Tidak suka & 2 & 18 \\
Jumlah & 11 & 100 \\
\hline
\end{tabular}

\section{RUJUKAN}

1. Suwitra K. Penyakit Ginjal Kronik. In: Sudoyo AD et al, editors. Buku Ajar IImu Penyakit Dalam. Jakarta: FK UI; 2006. p. 581.

2. Djarwoto B, Sja'bani M. Nutrisi pada Gagal Ginjal. In: Asdie AH, editor. Naskah Lengkap Pertemuan IImiah Tahunan IImu Penyakit Dalam FK UGM. Yogyakarta: Medika FK UGM; 2000. p. 118.

3. Klahr S. Effect Malnutrition and Change in Protein Intake on Renal Disease. In: Kopple JD, Massry SG, editors. Nutritional Management of Renal Disease. Philadelphia: Lippincott Williams \& Wilkins; 2003. p.219
4. Krenitsky J. Nutrition in Renal Failure: Myths and Management. In: Parrish CR, editors. Nutrition Issue In Gastroenterology. Series 20. Practical Gastroenterology [serial online]. September 2004 [cited 2007 Jun 5]. Available from: http://www.healthsystem.virginia.edu/ internet/digestive-health/nutritionarticles/ KrenitskyArticle.pdf.

5. Kresnawan T. Penatalaksanaan Diet pada Penyakit Ginjal Kronik. In: AsDI, editor. Prosiding Pertemuan IImiah Nasional (PIN) II. Bandung: AsDI Cabang Jawa Barat; 2005. p.193. 
6. Prakorso MI. Pelayanan Gizi pada Gagal Ginjal Kronik. In: Sidabutar RP, Suhardjono, editors. Gizi pada Gagal Ginjal Kronik. Jakarta: Perhimpunan Nefrologi Indonesia; 1992. p. 22.

7. Taigo G, Aparicio M, Attman PO, et al. Expert Working Group Report on Nutrition in Adult Patients with Renal Insufficiency (Part 1 of 2). Consensus Report. Italy: Universita di Trieste; 2000. p.197-207.

8. ESPEN. Guidelines on Enteral Nutrition. Adult Renal Failure [serial online] 2007 Jan-Mar [cited 2007 Jun 5]. Available from: www.espen.org.

9. Perhimpunan Dokter Spesialis Gizi Klinik Indonesia (PDGKI). Pedoman Praktis Pemilihan Formula Nutrisi Enteral. Jakarta: PDGKI; 2008.

10. Toigo G, Aparicio M, Attman PO, Cano N, Cianciaruso $B$, Engel B, et al. Expert Working Group Report on Nutrition in Adult Patients with Renal Insufficiency (Consensus Report Part 1 of 2). Clin Nutr 2000;19:197-207.

11. Sastroasmoro S, Ismael S. Dasar-Dasar Metodologi Penelitian Klinis. Jakarta: Bina Rupa Aksara; 1995.

12. Lemeshow S, Hosmer D, Klar J. 1990. Adequacy of Sample Size in Health Studies. (Terjemahan) Pramono D. Yogyakarta: UGM Press; 1997. h. 49-52.

13. Almatsier S. Prinsip Dasar Ilmu Gizi. Jakarta: Gramedia; 2003.

14. Mandayam S, Mitch WE. Dietary Factors in The Treatment of Chronic Kidney Disease. In: Schrier RW, editor. Disease of the Kidney and Urinary Tract. Philadelphia: Lippincott Williams \& Wilkins; 2007.

15. Kossi ME, Nahas ME. Epidemiology and Pathophysiology of Chronic Kidney Disease: Natural History, Risk Factor, and Management. In: Feehally J Floege, J Johnson R, editors. Comprehensive Clinical Nephrology. London: Mosby; 2000.
16. Sunaryo A. Pengaruh Diet Rendah Protein Modifikasi terhadap Keseimbangan Nitrogen pada Pasien Penyakit Ginjal Kronik Predialisis di RSU Dr. Soeradji Tirtonegoro Klaten [tesis]. Yogyakarta: Universitas Gadjah Mada; 2000.

17. Caravaca F, Arrobas M, Pizarro JL, Casado ES. Uremic Symptoms, Nutritional Status, and Renal Function in PreDialysis End-Stage Renal Failure Patiens. Spain: Hospital Universitario Infanta Cristina Cristina Spain; 2001. p. 776-8.

18. Linholm B, Heimburger $O$, Stenvinkel $P$, Bergstrom J. Uremix Toxicity. In: Kopple J, Massry SG, editors. Nutritional Management of Renal Disease. Philadelphia: Lippincott Williams \& Wilkins; 2003. p. 67.

19. Djarwoto B. Anatomi-Fisiologi Ginjal Pengertian, Klasifikasi \& Etiologi Penyakit Ginjal Kronik. In: Minat Utama Gizi dan Kesehatan UGM. Materi Short Course Manajemen Gizi Penyakit Ginjal Kronik (PGK). Yogyakarta: Minat Utama Gizi dan Kesehatan UGM FKUGM; 2007.

20. Kopple JD. Nutritional Management of Nondialyzed Patients with Chronic Renal Failure. In: Kopple J, Massry SG, editors. Nutritional Management of Renal Disease. Philadelphia: Lippincott Williams \& Wilkins; 2003. p. 388-9.

21. Triyani. Penatalaksanaan Diet Mutakhir pada Penyakit Ginjal dan Saluran Kemih. In: Departemen Kesehatan RI. Pelatihan Pengelola Gizi Rumah Sakit Di Bidang Dietetik dan Kuliner di BLKM Departemen Kesehatan RI. Jakarta: Departemen Kesehatan RI; 1992.

22. Sidabutar RP. Gagal Ginjal Kronik. Jakarta: Perhimpunan Nefrologi Indonesia; 1992.

23. Gibson R. Principle of Nutritional Assessment. Second Edition. New York: Oxford University Press; 2005. p. 407. 